\title{
Molecular Identification, Reverse Transcription-Polymerase Chain Reaction Detection, Host Reactions, and Specific Cytopathology of Artichoke yellow ringspot virus Infecting Onion Crops
}

\author{
Varvara I. Maliogka, Chrisostomos I. Dovas, Dietrich E. Lesemann, Stephan Winter, and Nikolaos I. Katis
}

\begin{abstract}
First, second, and fifth authors: Plant Pathology laboratory, Faculty of Agriculture, Aristotle University of Thessaloniki, P.O. Box 269, 54124 Thessaloniki, Greece; second author: National Agricultural Research Foundation, Plant Protection Institute, P.O. Box 324, 57001 Thermi, Thessaloniki, Greece; third author: Biologische Bundesanstalt für Land- und Forstwirtschaft (BBA), Inst. für Biochemie und Pflanzenvirologie, Braunschweig, Germany; and fourth author: German Collection of Microorganisms and Cell Cultures, Division of Plant Virology, Braunschweig, Germany.
\end{abstract}

Accepted for publication 19 January 2006.

\begin{abstract}
Maliogka, V. I., Dovas, C. I., Lesemann, D. E., Winter, S., and Katis, N. I. 2006. Molecular identification, reverse transcription-polymerase chain reaction detection, host reactions, and specific cytopathology of Artichoke yellow ringspot virus infecting onion crops. Phytopathology 96:622-629.

An isometric virus ca. $25 \mathrm{~nm}$ in diameter with angular contour was isolated from onion plants showing yellow leaf striping and necrotic tips. The virus was mechanically transmitted onto 28 species of indicator plants belonging to five families, viz. Amaranthaceae, Chenopodiaceae, Cucurbitaceae, Leguminosae, and Solanaceae where it causes ring spots, malformations, and/or tip necrosis. Cytopathological studies in infected

Nicotiana benthamiana tissues revealed cytoplasmic inclusions resembling those caused by Artichoke yellow ringspot virus (AYRSV), a member of the family Comoviridae. Host range and symptomatology of the onion virus were also similar to AYRSV. A high seed transmission rate (20\%) was found in onion. Reverse transcription-polymerase chain reaction using degenerate primers specific for the family Comoviridae allowed amplification of RNA-dependent RNA polymerase sequences, which upon sequence analysis and comparison with AYRSV isolates from Cynara scolymus (AYRSV-AtG) and Vicia faba (AYRSV-F) were highly similar, thus providing evidence that the nepovirus AYRSV is infecting onion in the field.
\end{abstract}

The cultivated onion (Allium cepa L. var. cepa) is one of the most important crops of the family Alliaceae with worldwide cultivation (Asia, United States, and Mediterranean countries) (48). In Greece, although small-sized onion farms are scattered throughout the country, it is grown mainly in the South on a total area of 9,000 ha, with increasing economic impact. More than 20 viruses belonging mainly to the genera Potyvirus, Carlavirus, Allexivirus, and Tospovirus have been reported to affect onion crops worldwide, causing high qualitative and quantitative losses $(3,4,8,33$, $49,50,53$ ). In Greece, Onion yellow dwarf virus (OYDV) was the only virus detected in onion crops during a survey throughout the country (9). However, in 1998, onion samples from Corinthos (Peloponnesos, Southern Greece), showing virus-like leaf symptoms but different from those caused by OYDV, arrived in our lab. These symptoms have appeared in onion crops of Corinthos for about 15 years and have not been encountered in any other onion cultivating region of Greece. Disease incidence varied between 5 to $80 \%$ from year to year and affected almost all onion fields. The disease appeared usually in already developed plants $(50 \mathrm{~cm}$ high) which showed yellow stripes and necrotic tips on the leaves (Fig. 1). An isometric virus with similarities to nepoviruses in host range and symptomatology was isolated from symptomatic onion plants and here we report its partial characterization.

Corresponding author: N. I. Katis; E-mail address: katis@ agro.auth.gr

The nucleotide sequences reported in this work have been deposited in the EMBL databank under the accession nos. AM087671, AM087672, and AM087673.

DOI: 10.1094/PHYTO-96-0622

(C) 2006 The American Phytopathological Society

\section{MATERIALS AND METHODS}

Host range and symptomatology. Young onion leaves showing severe symptoms were ground in $0.1 \mathrm{M}$ phosphate buffer (PB), $\mathrm{pH} 7.0$, and the extract was mechanically inoculated onto Carborundum-dusted leaves of test plants. Two plants each of 44 species belonging to eight families were inoculated (Tables 1 and 2 ). The presence of the virus in symptomless test plants was evaluated by back inoculation onto Chenopodium quinoa. In order to reproduce disease symptoms, onion seedling plants (cvs. Aridaia and Thiva) were also mechanically inoculated with extracts from infected test plants and/or diseased onion field plants.

Seed transmission. Seed transmission of the onion virus was tested in seed batches collected from naturally infected onion plants and mechanically inoculated Nicotiana benthamiana and Gomphrena globosa plants. In all cases, infected plants were kept until seed maturation and collected seeds were sown in steamsterilized peat after 1 month storage at $36^{\circ} \mathrm{C}$. Infected plants were identified by the symptoms developed and/or by bioassays onto Chenopodium quinoa and $N$. benthamiana plants. In addition, all symptomatic onion plants originating from infected seed were tested by reverse transcription-polymerase chain reaction (RTPCR) for the presence of Artichoke yellow ringspot virus (AYRSV) (described below).

Electron microscopy and serology. Leaves of mechanically inoculated $N$. benthamiana plants showing severe symptoms were used for all electron microscopy (EM) studies and serological tests, 2 to 3 weeks postinoculation. Adsorption preparates were made with plant extracts in PB negatively stained with $1 \%$ uranyl acetate (UAc) and examined under an electron microscope (Zeiss EM 906; Zeiss, Oberkochen, Germany). Spray preparates negatively stained with $2 \%$ aqueous Na-phosphotungstate (PTA), $\mathrm{pH}$ 
7.0, were made by squashing leaf tissue directly in the stain and spraying the PTA-diluted extracts with a spray gun onto Pioloform-carbon coated grids (28).

For cytopathological analysis, leaf tissue from three different infected plants of $N$. benthamiana and one infected onion plant was prepared essentially according to the procedure described by Koenig and Lesemann (18). Tissue pieces were fixed in $2.5 \%$ glutaraldehyde in PB for $1 \mathrm{~h}$ at room temperature following their

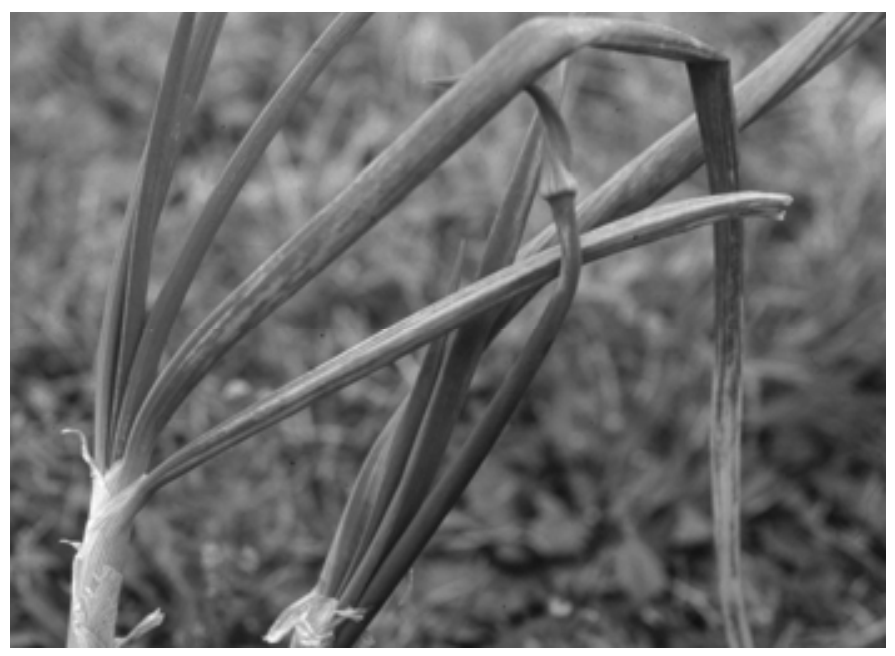

Fig. 1. Yellow leaf striping on Artichoke yellow ringspot virus-infected onion plants. infiltration for a few minutes under vacuum. Tissue samples were then washed in $\mathrm{PB}$ and post-fixed in $0.5 \% \mathrm{OsO}_{4}$ in the same buffer for $1 \mathrm{~h}$. The samples were washed again with PB, blockstained overnight in $1 \%$ uranyl acetate, and dehydrated by graded acetone dilutions followed by an acetone-Epon mixture $(1: 1)$. After two final passages in pure Epon, the fragments were embedded in Epon and ultrathin sections were obtained with a diamond knife in an LKB ultratome III ultramicrotome (LKB, Rockville, MD).

Direct and indirect enzyme-linked immunosorbent assays (ELISA) were performed $(7,52)$, using antisera against the following viruses that infect the family Alliaceae (9): OYDV, Leek yellow stripe virus, Garlic common latent virus, Shallot latent virus, Garlic virus $C$, Garlic virus D, Tomato black ring virus (TBRV), Arabis mosaic virus (ArMV), Iris yellow spot virus, and Tomato spotted wilt virus.

To evaluate serological relationships with members of the genus Nepovirus, immunosorbent electron microscopy (ISEM) and decoration tests were performed as described by Milne and Lesemann (29) and Milne (28) using antisera against the following approved and tentative nepoviruses: ArMV, Arracacha virus B (AVB) (recently redefined as a member of the new genus Cheravirus) (23), Artichoke Italian latent virus, AYRSV, Bean Ethiopean virus (H. J. Vetten, Braunschweig, personal communication), Cherry leafroll virus (CLRV), Cherry rasp leaf virus (CRLV), Grapevine Bulgarian latent virus, Grapevine chrome mosaic virus (GCMV), Grapevine fanleaf virus (GFLV), Grapevine Tunisian ringspot virus, Mulberry ringspot virus, Myrobalan latent ringspot virus, Olive latent ringspot virus, Peach rosette mosaic virus, Potato black ringspot virus (PBRSV), Potato virus $U$, Raspberry ring-

TABLE 1. Reactions of test plants sap-inoculated with different Artichoke yellow ringspot virus (AYRSV) isolates ${ }^{\mathrm{a}}$

\begin{tabular}{|c|c|c|c|c|c|c|c|c|c|c|}
\hline \multirow[b]{3}{*}{ Family/host species } & \multirow{2}{*}{\multicolumn{2}{|c|}{$\frac{\text { AYRSV-On }^{\mathrm{b}}}{\text { Symptoms }}$}} & \multirow{2}{*}{\multicolumn{2}{|c|}{$\frac{\text { AYRSV-AtG }^{\mathrm{c}}}{\text { Symptoms }}$}} & \multirow{2}{*}{\multicolumn{2}{|c|}{$\frac{\text { AYRSV-CaPa }^{\mathrm{d}}}{\text { Symptoms }}$}} & \multirow{2}{*}{\multicolumn{2}{|c|}{$\frac{\text { AYRSV-Fe }}{\text { Symptoms }}$}} & \multirow{2}{*}{\multicolumn{2}{|c|}{$\begin{array}{l}\text { AYRSV-C } \\
\text { Symptoms }\end{array}$}} \\
\hline & & & & & & & & & & \\
\hline & Local & Systemic & Local & Systemic & Local & Systemic & Local & Systemic & Local & Systemic \\
\hline \multicolumn{11}{|l|}{ Amaranthaceae } \\
\hline Gomphrena globosa & rLL, yLP & RS, yLP, Ma & rLL, yLP & RS, yLP, Ma & rLL, yLP & RS, yLP, Ma & rLL & Ma, RS & $\mathrm{cRS}, \mathrm{nRS}$ & Mo \\
\hline Beta vulgaris & - & - & _- & - & - & _- & - & - & $\mathrm{rRS}$ & $\mathrm{rRS} \mathrm{Ma}$ \\
\hline Chenopodium amaranticolor & cLL & $\mathrm{Ma}, \mathrm{TN}$ & cLL & $\mathrm{Ma}, \mathrm{TN}$ & cLL & $\mathrm{Ma}, \mathrm{TN}$ & cLL & Mo, Ma, TN & $\mathrm{c}$ & Mo, Ma, TN \\
\hline Chenopodium murale & nLL & $\mathrm{TN}$ & $\mathrm{nLL}$ & $\mathrm{TN}$ & nLL & $\mathrm{TN}$ & NT & NT & NT & NT \\
\hline Chenopodium quinoa & cLL, nLL & $\mathrm{TN}$ & $\mathrm{nLL}$ & $\mathrm{Ma}, \mathrm{TN}$ & nLL & Mo, TN & cLL & $\mathrm{Mo}, \mathrm{Ma}, \mathrm{TN}$ & $\mathrm{c}$ & Mo, Ma, TN \\
\hline Spinacia oleraceae & - & Drf & NT & NT & SI & - & - & SI & NT & NT \\
\hline \multicolumn{11}{|l|}{ Cucurbitaceae } \\
\hline Cucumis sativus cv. Knossos & - & $\mathrm{E}$ & NT & NT & NT & NT & cLL & Mo, E, Drf & $\mathrm{c}$ & Mo, E, Drf \\
\hline \multicolumn{11}{|l|}{ Leguminosae } \\
\hline Phaseolus vulgaris Saxa & rLL & $\mathrm{M}, \mathrm{Ma}$ & rLL & VC, yMo & rLL & $\mathrm{nM}, \mathrm{Ma}$ & NT & NT & NT & NT \\
\hline Vicia faba L. var. major & - & - & - & - & SI & SI & rLL & Mo, Ma, Drf & - & SI \\
\hline \multicolumn{11}{|l|}{ Solanaceae } \\
\hline Capsicum аппиит & - & - & - & - & - & - & - & - & - & - \\
\hline Datura metel & - & $\mathrm{VC}$ & NT & NT & NT & NT & - & - & - & Mo \\
\hline D. stramonium & - & M & - & - & RS & - & NT & NT & $\mathrm{N}$ & Mo \\
\hline Nicotiana benthamiana & yRS & $\begin{array}{l}\text { yRS, M, } \\
\text { Ma, LP }\end{array}$ & RS & M, Ma, RS & RS & M, Ma & - & Mo & - & Mo, LP, N \\
\hline N. clevelandii & RS & RS, LP & RS & RS & RS & RS & - & $\mathrm{cRS}, \mathrm{nRS}$ & - & cRS, nRS, LP \\
\hline N. debney & cRS & M, nLP & cMo & - & cMo & SI & NT & NT & NT & NT \\
\hline N. glutinosa & LP, cRS & $\mathrm{M}, \mathrm{RS}$ & $\mathrm{cRS}$ & - & $\mathrm{cRS}$ & cRS & - & - & NT & SI \\
\hline N. rustica & - & - & SI & yRS & yRs & yLP, RS & - & $\mathrm{cRS}, \mathrm{nRS}$ & - & cRS, LP \\
\hline N. tabacum cv. Samsun & $\mathrm{RS}$ & cMo, LP & SI & cMo & $\mathrm{cRS}$ & yRS & - & $\mathrm{cRS}, \mathrm{nRS}$ & $\mathrm{cRS}, \mathrm{nRS}$ & $\mathrm{cRS}, \mathrm{LP}$ \\
\hline N. tabacum cv. White Burley & cLL & M & cLL & cRS & cRS & yRS & - & $\mathrm{cRS}, \mathrm{nRS}$ & $\mathrm{cRS}, \mathrm{nRS}$ & cRS, LP \\
\hline N. tabacum cv. Xanthi & cRS & yRS, M & SI & yRS & cRS & yRS & - & $\mathrm{cRS}, \mathrm{nRS}$ & $\mathrm{cRS}, \mathrm{nRS}$ & cRS, LP \\
\hline Petunia hybrida & cRS & $\mathrm{cRS}, \mathrm{Ma}$ & SI & SI & Mo & Mo & - & $\mathrm{cRS}, \mathrm{nRS}$ & - & $\mathrm{cRS}$ \\
\hline Physalis floridana & nLL & - & NT & NT & SI & VC, M & NT & NT & $\mathrm{nRS}$ & $\mathrm{nRS}$ \\
\hline
\end{tabular}

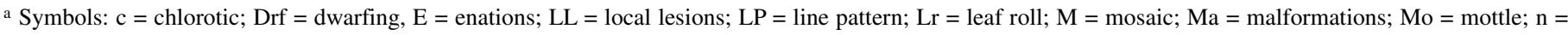
necrotic; NT = not tested; $\mathrm{r}=$ reddish; $\mathrm{RS}=$ ring spot; $\mathrm{SI}=$ symptomless infection; $\mathrm{TN}=$ top necrosis; $\mathrm{VC}=$ vein clearing; $\mathrm{y}=\mathrm{yellow}$; and $-=$ no infection.

b AYRSV-On: data obtained during this study.

c AYRSV-AtG (isolate from artichoke): host range and symptomatology from Rana et al. (35).

d AYRSV-CaPa (isolate from cardoon): host range and symptomatology from Rana et al. (35).

e AYRSV-F (isolate from Vicia faba): host range and symptomatology from Avgelis et al. (1).

f AYRSV-C (isolate from Cucumis sativus): host range and symptomatology from Avgelis and Vovlas (2). 
spot virus, Strawberry latent ringspot virus, Sweet potato ringspot virus, Tobacco ringspot virus (TRSV), TBRV, and Tomato ringspot virus. All antisera used for ISEM and decoration tests were from the collection of the electron microscopy lab at BBA, Braunschweig.

Molecular characterization and specific detection of the virus RNA extraction and RT-PCR amplification. Total plant RNA was extracted from infected onion, Chenopodium quinoa, and $N$. benthamiana plants according to Rott and Jelkmann (39). A 750-bp portion of the RNA-dependent RNA polymerase (RdRp) domain of the onion virus genome was amplified and sequenced according to a previously described nested RT-PCR developed for the generic detection of Comoviridae species (26). Two AYRSV isolates, AYRSV-AtG from Cynara scolymus (22) and AYRSV-F from Vicia faba L. (1), were also subjected to PCR of the RdRp region.

Sequencing and phylogenetic analysis. PCR products obtained from nested RT-PCR amplifications were separated by electrophoresis on $1.5 \%$ agarose gels, excised, and purified using a matrix gel extraction system (Marligen Bioscience, Ljamsville, MD). They were subsequently cloned in the pCR2.1 vector using the TA cloning Kit (Invitrogen, The Netherlands). Plasmid DNA was extracted from bacterial cells using the "Nucleobond" plasmid purification system (Macherey-Nagel, Germany) and both strands of the inserted DNA were sequenced. Sequencing was performed by the dideoxynucleotide termination cycle sequencing method with an ABI Prism 3700 DNA Analyser, using

TABLE 2. Reaction of test plants sap-inoculated with Artichoke yellow ringspot virus-onion isolate

\begin{tabular}{|c|c|c|}
\hline \multirow[b]{2}{*}{ Family/host species } & \multicolumn{2}{|c|}{ Symptoms ${ }^{\mathrm{a}}$} \\
\hline & Local & Systemic \\
\hline \multicolumn{3}{|l|}{ Alliaceae } \\
\hline Allium cepa $\mathrm{cv}$. Thiva & - & - \\
\hline Allium cepa cv. Aridaia & - & - \\
\hline Allium cepa cv. Red & - & - \\
\hline Allium cepa cv. Brown & - & - \\
\hline \multicolumn{3}{|l|}{ Chenopodiaceae } \\
\hline Chenopodium capitatum & $\mathrm{nLL}$ & $\mathrm{TN}$ \\
\hline Chenopodium foliosum & cLL, nLL & $\mathrm{TN}$ \\
\hline \multicolumn{3}{|l|}{ Compositae } \\
\hline Lactuca sativa cv. Salad & - & - \\
\hline \multicolumn{3}{|l|}{ Cucurbitaceae } \\
\hline Cucurbita melo Brida F1 & - & - \\
\hline Cucurbita pepo Jedida F1 & - & - \\
\hline \multicolumn{3}{|l|}{ Leguminosae } \\
\hline Lupinus angustifolius & - & - \\
\hline Lupinus polyphyllus & - & - \\
\hline Phaseolus vulgaris Black Turtle I & - & - \\
\hline Phaseolus vulgaris Black Turtle II & - & - \\
\hline Pisum sativum Allerfruheste & - & - \\
\hline Pisum sativum Schalberse & - & - \\
\hline Vigna sinensis Ife Brawn & rLL & - \\
\hline Vigna sinensis Vita 5 & rLL & rLL \\
\hline \multicolumn{3}{|l|}{ Solanaceae } \\
\hline Capsicum westca & - & - \\
\hline Emilia sonchifolia & SI & SI \\
\hline Lycopersicon esculentum Alma F1 & - & M \\
\hline Lycopersicon esculentum Linda & - & - \\
\hline Lycopersicon esculentum Vollendung & - & - \\
\hline Nicotiana hesperis & M, NLP & M, NLP \\
\hline N. occidentalis obliqua & nRS & RS \\
\hline N. sylvestris & RS & RS \\
\hline Solanum demissum & NLL & LM, NRS, M \\
\hline \multicolumn{3}{|l|}{ Umbelliferae } \\
\hline Ammi majus & - & - \\
\hline Apium graveolens & - & - \\
\hline Coriandrum sativum & - & - \\
\hline
\end{tabular}

a Symbols: $\mathrm{c}=$ chlorotic; $\mathrm{LL}=$ local lesions; $\mathrm{LP}=$ line pattern; $\mathrm{M}=$ mosaic; $\mathrm{n}=$ necrotic $; \mathrm{r}=$ reddish $; \mathrm{RS}=$ ring spot; $\mathrm{SI}=$ symptomless infection; $\mathrm{TN}=$ top necrosis; and $-=$ no infection.
ABI PRISM BigDye Terminators version 3.0 Cycle Sequencing Kit (Applied Biosystems, Foster City, CA).

For sequence analysis, the partial RdRp of AYRSV and of corresponding sequences from members of picorna-like plant viruses (26) were translated to amino acid sequences and analyzed using the Clustal X (47) alignment routine. Clustal alignments were used for inferring phylogenetic trees using the neighbor-joining method developed by Saitou and Nei (41). To determine the confidence values for the grouping within a tree, a bootstrap analysis (10) was performed using 1,000 replicates of the data.

Virus-specific RT-PCR detection. Two virus-specific primers were designed after aligning the corresponding partial RdRp sequences obtained from AYRSV-AtG, AYRSV-F, and the onion isolate. The primers were denoted AYRSVup11, 5'-GAACGCAACATCGGAGA-3', and AYRSVd12, 5'-GCTCCACAAAGTGACTTG-3'. An RT-PCR assay was developed in two separate tubes for the specific detection of AYRSV in infected plants by amplifying a genome fragment of $530 \mathrm{bp}$. To test for specificity of RTPCR, total RNA from different AYRSV-infected hosts (Allium cepa, Cynara scolymus, Vicia faba, and Silybum marianum) and from plants infected with other nepoviruses (PBRSV, TRSV, GFLV, CLRV, and ArMV) were subjected to nucleic acid amplification. To confirm the association of AYRSV with the onion disease, 20 onion samples collected from affected crops in Corinthia area showing typical yellow striping symptoms and 10 asymptomatic onion plants from the same fields were included in the tests.

For reverse transcription, cDNA was prepared in a $15-\mu \mathrm{l}$ RT volume containing $50 \mathrm{mM}$ Tris- $\mathrm{HCl}(\mathrm{pH} 8.3), 75 \mathrm{mM} \mathrm{KCl}, 3 \mathrm{mM}$ $\mathrm{MgCl}_{2}, 1 \mu \mathrm{M}$ oligo (dT) $)_{18}$ primer, $10 \mathrm{mM}$ DTT, $0.5 \mathrm{mM}$ dNTP (each), 15 units of Ribonuclease inhibitor (HT Biotechnology, UK), $1 \mu \mathrm{l}$ of RNA extract, and 60 units of Moloney murine leukemia virus reverse transcriptase (MMLV, Invitrogen, the Netherlands). The mixture was incubated at $42^{\circ} \mathrm{C}$ for $1 \mathrm{~h}$ and then at $94^{\circ} \mathrm{C}$ for $5 \mathrm{~min}$. PCR $(20 \mu \mathrm{l})$ was performed using $1 \mu \mathrm{l}$ of the RT product. The reaction mixture contained $10 \mathrm{mM}$ Tris- $\mathrm{HCl}(\mathrm{pH}$ 8.8), $50 \mathrm{mM} \mathrm{KCl}, 1.5 \mathrm{mM} \mathrm{MgCl}_{2}, 0.1 \%$ Triton X-100, $0.2 \mathrm{mM}$ of each dNTP, and 0.5 units of Dynazyme II DNA Polymerase (Finnzymes, Finland). The cycling profile was as follows: first step at $94^{\circ} \mathrm{C}$ for $2 \mathrm{~min}$ followed by 40 cycles segmented in $30 \mathrm{~s}$ at $95^{\circ} \mathrm{C}, 30 \mathrm{~s}$ at $57^{\circ} \mathrm{C}$, and $20 \mathrm{~s}$ at $72^{\circ} \mathrm{C}$, and a final extension step at $72^{\circ} \mathrm{C}$ for $4 \mathrm{~min}$.

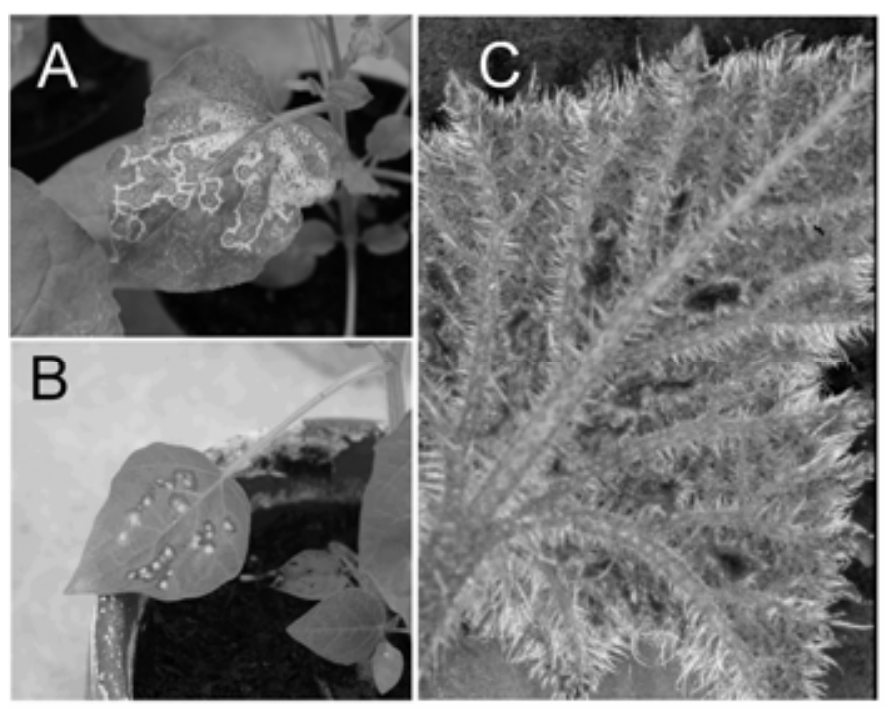

Fig. 2. Symptoms induced on leaves of herbaceous test plants following mechanical inoculation with the onion isolate of Artichoke yellow ringspot virus, using extracts from symptomatic onion. A, Ring spots and line patterns in Nicotiana benthamiana. B, Necrotic local lesions in Physalis floridana. C, Enations on Cucumis sativus cv. Knossos. 


\section{RESULTS}

Host range and symptomatology. Of the 44 plant species inoculated, 28 were susceptible to the onion isolate (Tables 1 and 2 ), with the majority of them showing typical nepovirus symptoms. For example, Chenopodium spp. developed systemic infections and tip necrosis, whereas concentric ring spot and mosaic symptoms were observed on systemically infected leaves of members of the family Solanaceae (Fig. 2A). More specifically, concentric ring spot and oak leaf patterns appeared on $N$. benthamiana and $N$. tabacum cv. Samsun that resembled those induced by various nepoviruses including AYRSV, whereas necrotic local lesions appeared on Physalis floridana 3 days postinoculation (Fig. 2B). Two host-plant species belonging to the family Leguminosae reacted with reddish local lesions and characteristic enations developed on the underside of Cucumis sativus leaves (Fig. 2C).

Seed transmission. Eight out of forty (20\%) onion seedlings raised from seeds of field-infected symptomatic plants showed yellow line patterns and spots on the leaves resembling symptoms observed in the field. Virus infection on these seedlings was confirmed both by mechanical inoculation onto N. benthamiana and by RT-PCR. No seed transmission was observed in $N$. benthamiana $(0 / 100)$ and G. globosa (0/24) seedlings raised from seeds ob-
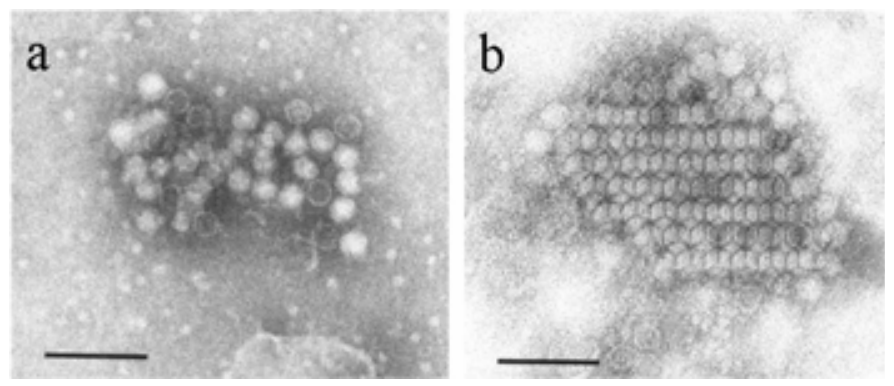

Fig. 3. Electron micrographs of Artichoke yellow ringspot virus particles in crude plant extract of infected Nicotiana benthamiana negatively stained with Na-phosphotungstate (PTA). a, Typical aggregate of mature virus particles mixed with empty shells. b, Crystal-like array of particles. Magnification bar $=100 \mathrm{~nm}$.

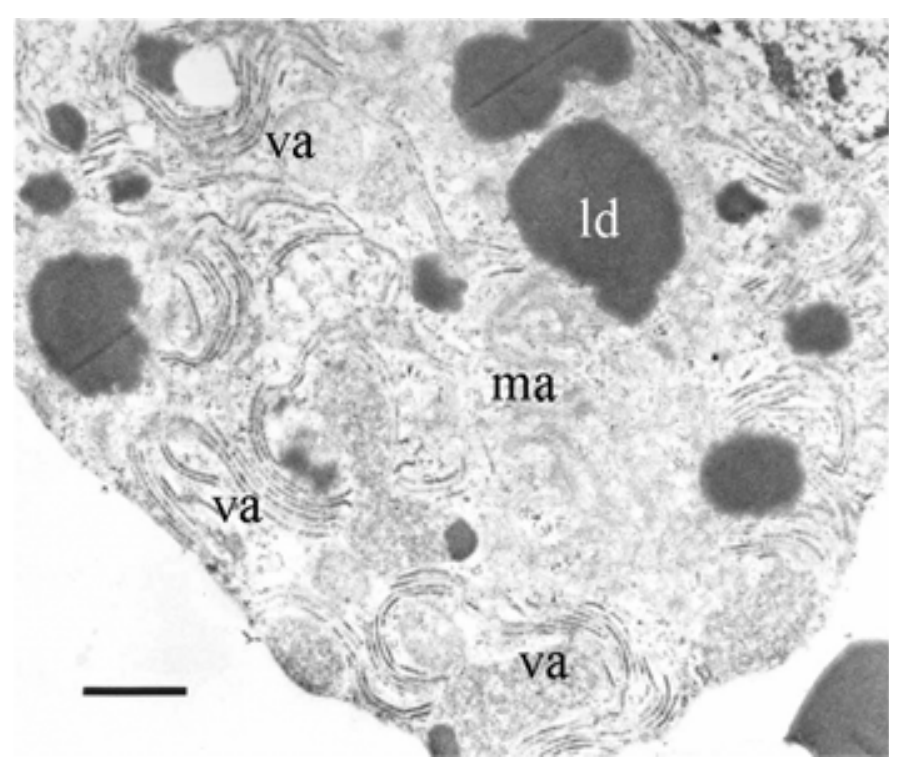

Fig. 4. Overview of a large virus-induced cytoplasmic inclusion in a leaf cell of Nicotiana benthamiana infected with Artichoke yellow ringspot virus (AYRSV)-On. Note voluminous membrane aggregates (ma), virus particle aggregates (va), and putative lipid droplets (ld). Magnification bar $=1 \mu \mathrm{m}$. All following cytological micrographs are also from infected $N$. benthamiana leaf cells. tained from severely infected plants. Phaseolus vulgaris cv. Saxa and Vigna sinensis cv. Vita 5 died upon virus infection; hence, seed transmission could not be determined for these species.

EM and serology. Low concentrations of isometric particles ca. $25 \mathrm{~nm}$ in diameter with angular outlines and comprising empty shells, which were penetrated by the stain, were observed in leaf extracts of infected $N$. benthamiana plants (Fig. 3a). The majority of particles were aggregated in irregular clumps or in crystal-like arrays (Fig. 3b). Single particles and their aggregates were more readily recognized in PTA-stained spray preparations than in UAc-stained adsorption preparations. This indicated a tendency of particles to only weakly adsorb to the support films on the grids.

Cytopathological analyses of leaf tissues of infected N. benthamiana revealed especially in mesophyll cells large cytoplasmic inclusions not occurring in cells of healthy tissues. The cytoplasmic inclusions comprised voluminous accumulations of entangled membranous elements, more or less developed, and specifically arranged particle aggregates and conspicuous globules of a supposed lipid nature (Fig. 4). The membrane accumulations mostly consisted of convoluted smooth elements, sometimes forming tightly entangled clusters and appearing to be continuous with cisternae of the rough endoplasmic reticulum (ER) (Fig. 5a).

A very characteristic and apparently specific cytopathologic structure occurred in many infected cells and in different stages of development and localizations (Figs. 5 to 7). This cytopathologic structure principally comprised complexes of two cisternae of rough ER in a parallel arrangement. The cisternae appeared to have a constant distance and to enclose between them specific material. In apparent early stages, the enclosed material is more or less dark stained and slightly granular (Fig. 5b to e). In further

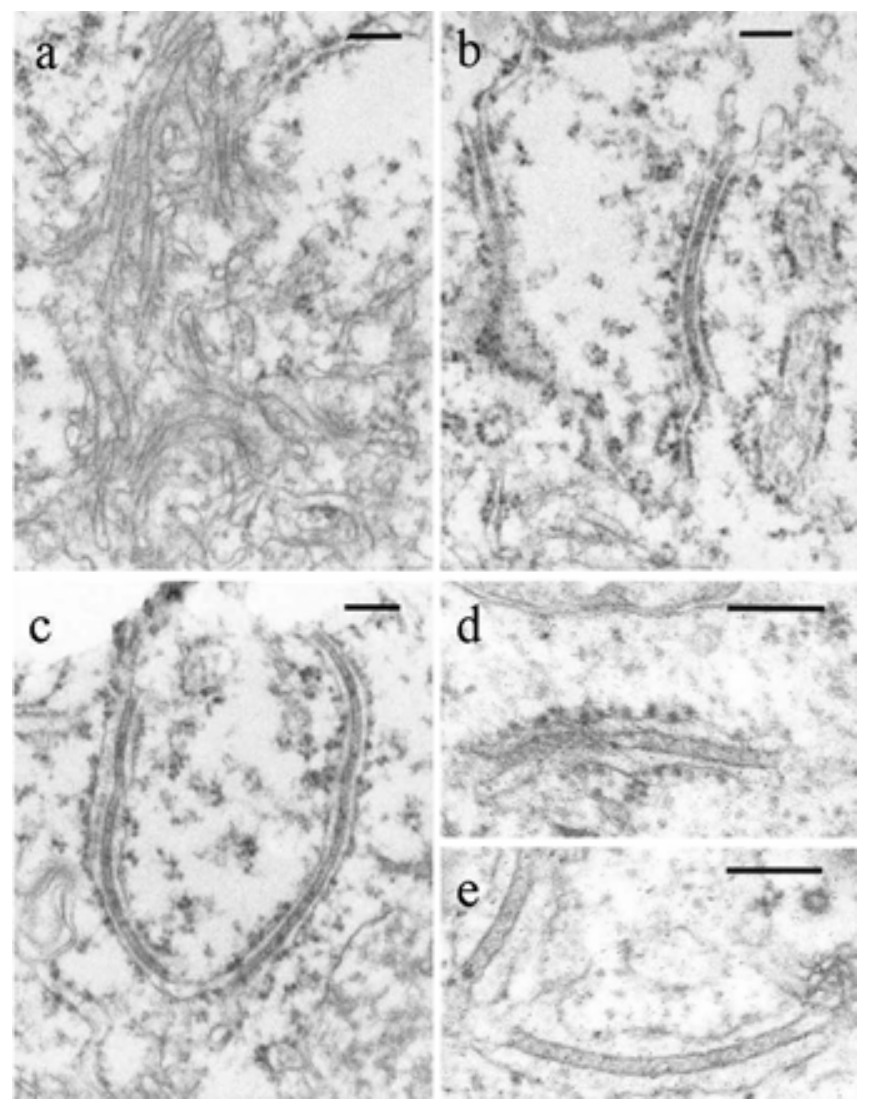

Fig. 5. Different aspects of membrane alterations: a, clusters of tightly entangled smooth membranes. b, clearly demonstrates the connection of the complex structure with rough endoplasmic reticulum (ER), c, illustrates the formation of the ER-derived structure on both sides of ER cisternae, and $\mathbf{d}$ and e, demonstrate higher magnifications of the dark stained granular material between the parallel-arranged ER cisternae. Magnification bars $=200 \mathrm{~nm}$. 
advanced stages, increasingly more particles of the virus are visible within the granular material (Fig. 6a and b). In the fully developed stage, the virus particles form more or less continuous apparent rows between the enclosing ER cisternae (Fig. 6b, inset). However, only in cross sections did such arrangements of virus particles appear as rows lined by ER cisternae, but when the particle aggregates were cut obliquely, it could be recognized that three dimensionally the aggregates were particle monolayers (Fig. $6 \mathrm{a}$ and $\mathrm{b}$, arrows). In Figure 7, an exceptionally massive accumulation of particle monolayers (Fig. 7, inset) is shown. Here, it can especially be recognized that within the layer the particles are arranged in crystal-like arrays (Fig. 7, arrows). In the stage represented by Figure 7, the particle layers appear to be arranged on both sides of extremely proliferated ER cisternae.

Occasionally, infected cells contained complexes of particle monolayers between one ER cisterna and a portion of the nuclear envelope double membrane or such ER complexes were merging with the nuclear membrane. A high proportion of infected cells contained virus particles in a second type of principal arrangement, which appeared as particle double layers not accompanied by membrane-like structural linings. These aggregates formed double rows in cross sections (Fig. 8a and b), and at section plains, oblique or almost parallel to the double particle layers, crystal-like particle arrays within these layers could be recognized (Fig. 8b, arrows).

In some cells, obvious dilatations of the nuclear membranes were observed, as described by Russo et al. (40), in AYRSV-

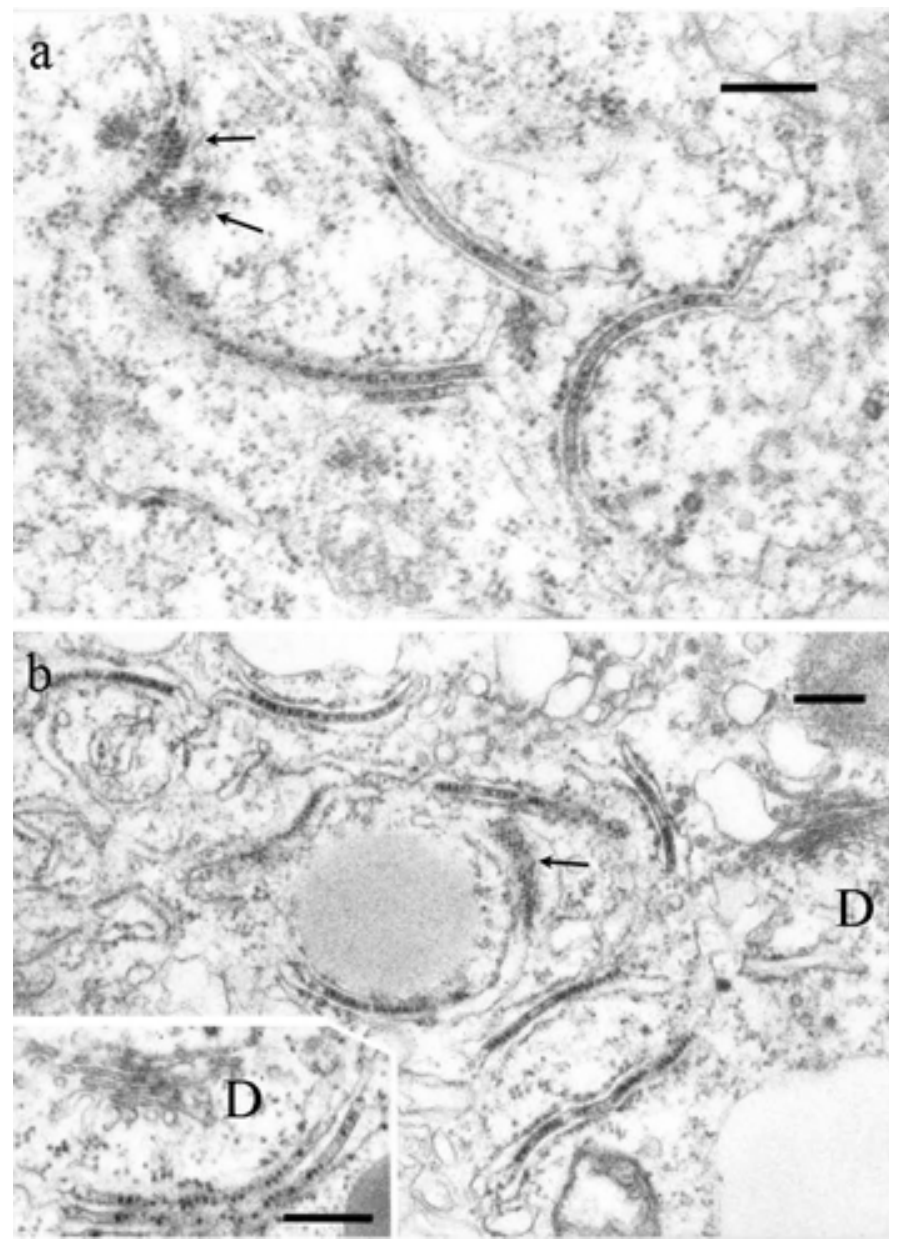

Fig. 6. Development of virus particle monolayers between parallel-arranged rough endoplasmic reticulum (ER) cisternae. a, Few particles enclosed within dark stained material. b, More complete rows of particles between the ER cisternae. a and $\mathbf{b}$, Particle arrays in obliquely cut portions of particle monolayers are seen (arrows). Note, in $\mathbf{b}$ and inset, no apparent connection between ER-virus complexes and dictyosomes (D). Magnification bars $=300 \mathrm{~nm}$. infected tissues. However, small vesicles formed in areas of dilatated nuclear envelope and single rows of virus particles within tubular membrane-like structures were not observed in our material. Very rarely, cell wall proliferations containing irregularly formed plasmodesma-like structures were recognized. Similar structures have been described with several members of the family Comoviridae. In one case, a putative virus particle array has been observed in the central part of a nucleus. A connection of the monolayer containing membrane complexes with dictyosomes, as suggested by Russo et al. (40), could not be observed (Fig. $6 \mathrm{~b}$ and inset).

Samples embedded from the infected onion plant yielded aspects of extremely vacuolated cells with very low concentrations of cell constituents and virus-induced cytological alterations. Apart from a principal similarity with $N$. benthamiana, the ex-

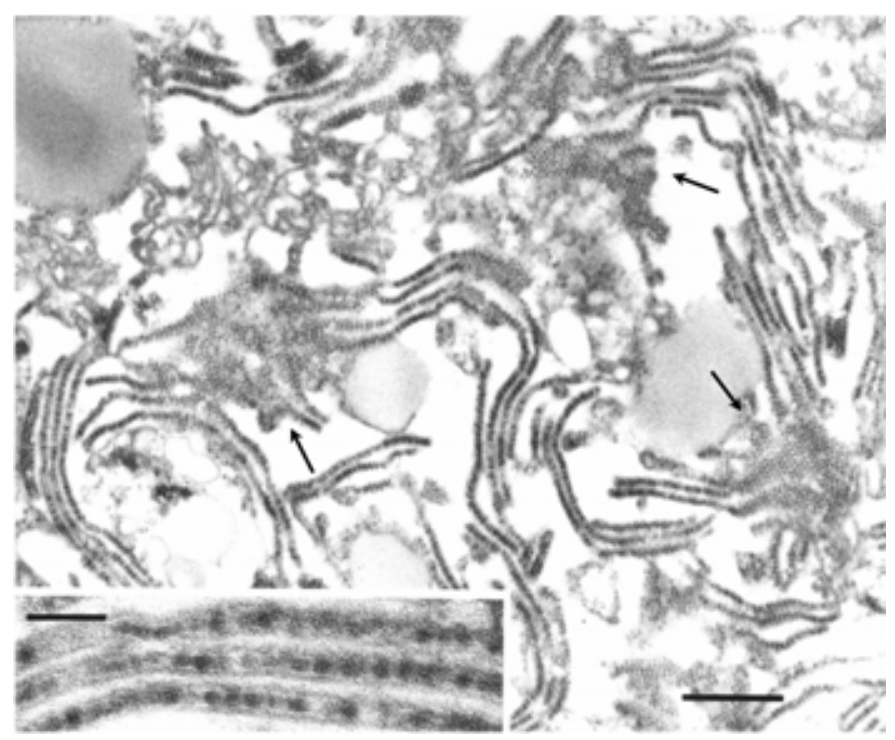

Fig. 7. Large accumulation of virus particle monolayers. The particle layers appear to be enclosed between membrane-like linings (inset). Cross-sectioned monolayers appear as particle rows, obliquely sectioned layers illustrate crystal-like array of particles in the monolayers (arrows). Magnification bars = $200 \mathrm{~nm}, 100 \mathrm{~nm}$ (inset).

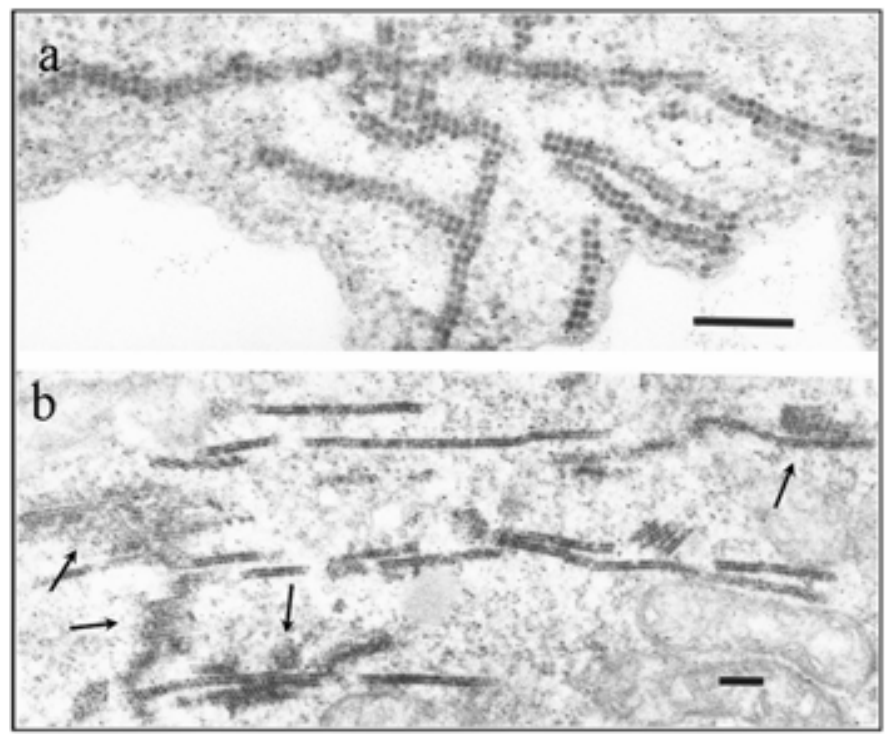

Fig. 8. Double layer virus particle aggregates. a, High magnification showing mainly cross sections as double rows and lack of membrane lining. b, Lower magnification of cross-sectioned double rows and obliquely sectioned double layers displaying crystal-like particle arrangements (arrows). Magnification bars $=200 \mathrm{~nm}$. 
tremely low quantity of relevant cell contents did not allow for a critical comparison.

For virus detection and identification, crude sap extracts of $N$. benthamiana plants infected with the onion virus subjected to ELISA, ISEM, and decoration tests did not react with any of the antisera used (described above). This was also the case with the positive controls of freeze-dried AYRSV-infected leaf tissues tested with homologous antiserum. AYRSV antiserum also did not react with the onion isolate in ISEM tests.

Molecular characterization and specific detection of the virus. Since the symptoms observed on different host plants indicated nepovirus infection, a protocol adapted from Stace-Smith et

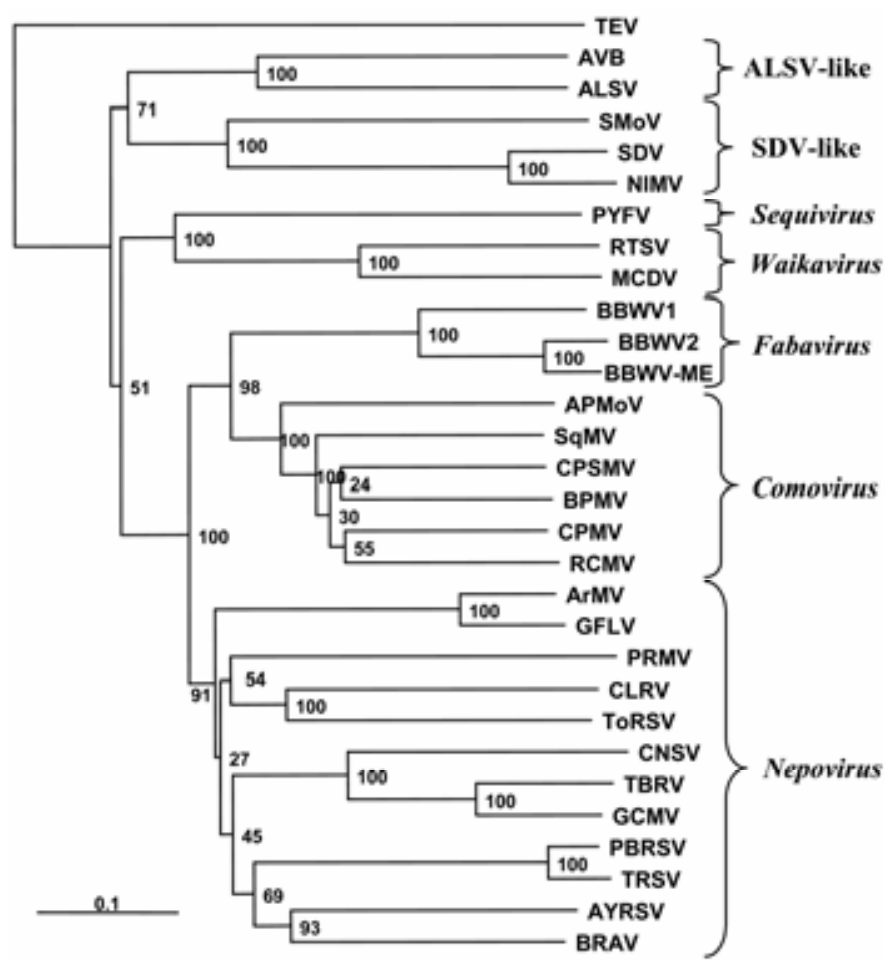

Fig. 9. Neighbor-joining tree generated from selected members of plant picornalike viruses, representing lineages of Sequiviridae, Comoviridae, Satsuma dwarf virus (SDV)-like, and Apple latent spherical virus (ALSV)-like viruses using the partial RNA-dependent RNA polymerase (RdRp) alignment (246263 amino acids) and showing the taxonomic positions of the respective sequence of Artichoke yellow ringspot virus (AYRSV) (onion isolate). Virus genera, with acronyms and Swiss Protein Translated European Molecular Biology Laboratory (SPTREMBL) database accession numbers in parenthesis are as follows. Nepoviruses: Blackcurrant reversion associated virus (BRAV, Q8V5E0), Tobacco ringspot virus (TRSV, Q88893), Potato black ringspot virus (PBRSV, Q6A2S5), Grapevine chrome mosaic virus (GCMV, P13025), Tomato black ring virus (TBRV, Q8B8X3), Cycas necrotic stunt virus (CNSV, Q8QVV0), Tomato ringspot virus (ToRSV, Q88876), Cherry leafroll virus (CLRV, Q6A2S6), Peach rosette mosaic virus (PRMV, O37086), Grapevine fanleaf virus (GFLV, P29149), and Arabis mosaic virus (ArMV, Q6A1Z2). Comoviruses: Red clover mottle virus (RCMV, P35930), Cowpea mosaic virus (CPMV, P03600), Bean pod mottle virus (BPMV, Q8JUF5), Cowpea severe mosaic virus (CPSMV, P36312), Squash mosaic virus (SqMV, Q91PR6), and Andean potato mottle virus (APMoV, Q02941). Fabaviruses: Broad bean wilt virus 2-Megakepasma erythrochlamys isolate (BBWV-ME, Q997D0), Broad bean wilt virus 2 (BBWV-2, Q9WNW0), and Broad bean wilt virus 1 (BBWV-1, BAD00183). Waikaviruses: Maize chlorotic dwarf virus (MCDV, O11979) and Rice tungro spherical virus (RTSV, Q98645). Sequiviruses: Parsnip yellow fleck virus (PYFV, Q05057). Unclassified SDV-like viruses: Navel orange infectious mottling virus (NIMV, Q9YZ97), Satsuma dwarf virus (SDV, Q9WAL8), and Strawberry mottle virus (SMoV, Q8UYV9). Unclassified ALSV-like viruses: Arracacha virus B (AVB, Q6A2S7) and Apple latent spherical virus (ALSV, Q9JGP2). Tobacco etch virus (TEV, PO4517), genus Potyvirus, was included in the analysis as an outgroup. The values at each branch indicate the percentages of bootstrap analysis, which support the grouping at each node. The scale bar shows the number of substitutions per base. al. (45) was used, although unsuccessfully, to purify the virus. EM examinations during the successive purification steps revealed the presence of virion aggregates in the initial steps only. Likewise, multiple attempts to isolate double-stranded RNA using a standard procedure described by Winter et al. (55) from leaves of symptomatic $N$. benthamiana plants harvested 2 weeks postinoculation were unsuccessful.

However, application of the nested RT-PCR method developed for the generic detection of Comoviridae species (26) gave the expected amplicon (750 bp) for the onion virus and the AYRSVAtG and AYRSV-F isolates. Sequencing and comparison among the above cloned partial RdRp amplicons revealed $100 \%$ amino acid identity of the analyzed protein fragment and $93 \%$ nucleotide identity. Amino acid sequence analysis revealed significant homologies with corresponding RdRp regions of other members of the genus Nepovirus, with highest amino acid sequence similarity found with Blackcurrant reversion associated virus (BRAV) $(60 \%)$ and GFLV (52\%), respectively.

Phylogenetic analysis confirmed the classification of the AYRSV isolates as members of the genus Nepovirus, with AYRSV forming a cluster with BRAV, a virus that is classified as a mitetransmitted member of nepovirus subgroup C (Fig. 9).

All AYRSV isolates from different host plants were specifically detected by RT-PCR using the designed primers and amplifying a 530-bp DNA fragment (Fig. 10).

\section{DISCUSSION}

Partial characterization of a virus naturally infecting onions in Southern Greece and inducing yellow striping on the leaves revealed its taxonomic classification as an isolate of AYRSV. AYRSV onion isolate has features typical for nepoviruses, a wide host range with induced symptoms mainly consisting of mosaic, concentric line patterns, and ring spots (Solanaceae) or tip necrosis (Chenopodiaceae). Also, in most of the infected host plants, the recovery phenomenon has been observed and characterized by eventual lack of symptoms in the newly developed leaves. The virus particles resemble nepoviruses (and other Comoviridae) in their size, slightly angular outline and smooth surface structure as well as the production of empty shells. Like other nepoviruses and other Comoviridae species, the onion virus induces voluminous membrane-composed cytoplasmic inclusions.

The molecular characterization of the onion virus provided strong evidence that it is closely related to AYRSV. Its high nucleotide (93\%) and amino acid (100\%) sequence identity with

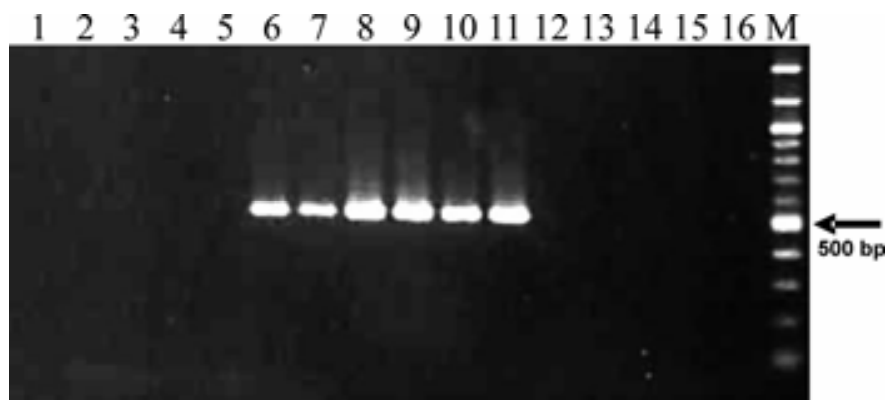

Fig. 10. Agarose gel electrophoretic analysis of reverse transcription-polymerase chain reaction products obtained from RNA leaf extracts of six different Artichoke yellow ringspot virus (AYRSV)-infected plants. Lane 1, Potato black ringspot virus in Solanum tuberosum; lane 2, Tobacco ringspot virus in Phaseolus vulgaris; lane 3, Grapevine fanleaf virus in Vitis vinifera; lane 4, Arabis mosaic virus in Rubus sp.; lane 5, Cherry leafroll virus in Fraxinus excelsior; lane 6, AYRSV-AtG in Cynara scolymus; lane 7, AYRSV-F in Vicia faba; lane 8, AYRSV-On in Allium cepa; lane 9, AYRSV-On in Gomphrena globosa; lane 10, AYRSV in Silybum marianum; lane 11, AYRSV-AtG in Nicotiana benthamiana; lane 12, healthy Cynara scolymus; lane 13, healthy $V$. faba; lane 14 , healthy A. cepa; lane 15, healthy $N$. benthamiana; lane 16, healthy G. globosa; and M, 100-bp DNA ladder. 
the RdRp gene of AYRSV from Cynara scolymus (AYRSV-AtG) and Vicia faba (AYRSV-F) $(1,22)$ support its classification as an AYRSV isolate, hereafter referred to as AYRSV-On.

However, cytopathological assessment of AYRSV-On-infected plant tissues revealed that virus particle arrangement in infected cells may not be typical of nepoviruses. The majority of the nepoviruses induce conspicuous virus particle aggregates in single rows enclosed within membrane-like tubules $(12,16,19,27,34$, $38,43,54)$. Similar particle arrangements have also been found within the genera Comovirus (14,17,51), Sequivirus (25,31), Cheravirus $(23,44)$, Sadwavirus $(13,24)$, Caulimovirus, Bromovirus, Tospovirus, and Umbravirus $(5,32)$ and Pelargonium zonate spot virus, a tentative member of the family Bromoviridae $(6,11)$.

In contrast, AYRSV-On induces predominantly particle aggregates in the form of crystal-like arrays either in particle monolayers enclosed between specially arranged ER cisternae or in double layers not enclosed between membrane elements. Our results are similar to those obtained by ultrastructural studies carried out with two other AYRSV isolates from Italy and Greece (40). The particle aggregates of AYRSV-On are distinct from those described for the majority of nepoviruses but resemble those of a few other members of the family Comoviridae (14, $16,30,42)$ and AYRSV earlier reported. The significance of the cytopathological differences is pending further studies, especially for taxonomic differentiation of subgroup $\mathrm{C}$ viruses BRAV and AYRSV.

Host range observations underline a similarity of AYRSV-On with other AYRSV isolates from artichoke, cardoon, cucumber, and Vicia faba $(1,2,35)$. For AYRSV, Cucumis sativus responded with enations upon infection and has been proven to be an indicator host of diagnostic value for all isolates (36). Table 1 illustrates that 14 test plant species reacted with similar symptoms upon inoculation with all AYRSV isolates collected from different hosts. However, N. rustica was immune to AYRSV-On but susceptible to the other isolates, whereas Physalis floridana reacted with necrotic local lesions to AYRSV-On and with different symptoms with two of the other isolates tested, indicating a small divergence within AYRSV isolates.

AYRSV was first described in artichoke (Cynara scolymus) in Southern Greece (Argolida), (21) and later in cardoon (Cynara cardunculus L.), tobacco ( $N$. tabacum), Vicia faba var. major, Cucumis sativus, and Vicia sativa in Italy and Greece (Crete) $(1,2,20,22,36,37,46)$. In all these studies, AYRSV identification was based on biological, biochemical, and ultrastructural data. This is the first report of AYRSV naturally infecting onions in Greece. AYRSV was found to be seed transmissible in a large number of natural and experimental hosts $(1,22,46)$. In this study, AYRSV-On was found to be seedborne in a local onion cultivar in a relatively high percentage $(20 \%)$ and therefore is the first seedtransmitted onion virus. This property, along with its wide host range and its putative transmissibility by pollen as described for AYRSV-AtG and AYRSV-F $(1,22)$ may play a fundamental role in AYRSV survival and perpetuation in nature.

The onion disease has been endemic for about 15 years in the area of Corinthos (southern Greece). Interestingly, the first observation of AYRSV in Greece was in an artichoke growing area, about $100 \mathrm{~km}$ from the infected onion fields. In Corinthos, onions are successively planted from the end of August until January using onion sets instead of seed and harvest ends by the beginning of May. Onion sets used are produced in Central Greece (Viotia) where the disease is not present and it is rather unlikely that the propagative material plays any epidemiological role. However, several volunteer onion plants do remain in the field during the entire year and they may play an important role as virus sources along with arable weeds and other susceptible cultivated plants such as Vicia faba that exist in the area $(1,22)$. The disease incidence varies within the region from year to year ranging from 5 to $80 \%$. Its distribution in affected field plots is erratic and its pres- ence is not persistent in the fields during repeated onion cultivation. Disease epidemic is favored by a warm, early spring, whereas dry climatic conditions do not favor its spread. The AYRSV incidence in a large number of cultivated and noncultivated host plants strongly suggests the involvement of a vector. As a nepovirus, AYRSV has been initially suggested to have a nematode vector but despite several attempts this could not be verified (1,2,22, and our own studies). Interestingly, AYRSV is forming a phylogenetic cluster with BRAV (Fig. 9), an eriophyid mite-transmitted virus (15). This correlation along with the epidemic behavior of AYRSV in onion, which resembles an airborne disease, suggest a possible mite transmission of the virus. However, this remains to be elucidated in future studies, possibly involving the mite Aceria tulipae that affects onion (D. Koveos, Thessaloniki, personal communication).

Serological detection and identification of AYRSV is problematic due to poor quality of available antisera as its purification has not been effective $(1,2,46$ and our studies). Specific sequence data for a number of isolates permitted us to design primers for the specific detection of AYRSV in all symptomatic onion plants and in several other infected host plants (Cynara scolymus, Vicia faba, G. globosa, N. benthamiana, and Silybum marianum [22]). This assay will be useful for further epidemiological studies and the search for the vector of AYRSV.

\section{ACKNOWLEDGMENTS}

We thank P. E. Kyriakopoulou (Agricultural University of Athens), A. D. Avgelis (Crop Protection Institute, Crete), and C. Varveri (Benaki Phytopathological Institute, Athens) for providing AYRSV antiserum and isolates.

\section{LITERATURE CITED}

1. Avgelis, A. D., Katis, N., and Grammatikaki, G. 1992. Broad bean wrinkly seed caused by Artichoke yellow ringspot nepovirus. Ann. Appl. Biol. 121:133-142

2. Avgelis, A. D., and Vovlas, C. 1989. Artichoke yellow ringspot nepovirus naturally infecting cucumber in Crete. Neth. J. Plant Pathol. 95:177-184.

3. Barg, E., Lesemann, D. E., Vetten, H. J., and Green, S. K. 1994. Identification, partial characterization, and distribution of viruses infecting Allium crops in South and South-East Asia. Acta Hortic. 358:251-258.

4. Barg, E., Lesemann, D. E., Vetten, H. J., and Green, S. K. 1997. Viruses of Alliums and their distribution in different Allium crops and geographical regions. Acta Hortic. 433:607-616.

5. Carvalho, C. M., Wellink, J., Ribeiro, S. G., Goldbach, R. W., and Van Lent, J. W. M. 2003. The C-terminal region of the movement protein of Cowpea mosaic virus is involved in binding to the large but not to the small coat protein. J. Gen. Virol. 84:2271-2277.

6. Castellano, M. A., and Martelli, G. P. 1981. Electron microscopy of Pelargonium zonate spot virus in host tissues. Phytopathol. Mediterr. 20:64-71.

7. Clark, M. F., and Adams, A. N. 1977. Characterization of the microplate method of enzyme-linked immunosorbent assay for the detection of plant viruses. J. Gen. Virol. 34:475-483.

8. Diekmann, M. 1997. FAO/IPGRI technical guidelines for the safe movement of germplasm. No 18. Allium spp. Food and Agriculture organisation of the United Nations, Rome/International Plant Genetic Resources Institute, Rome.

9. Dovas, C. I., Hatziloukas, E., Salomon, R., Barg, E., Shiboleth, Y., and Katis, N. I. 2001. Incidence of viruses infecting Allium spp. in Greece. Eur. J. Plant Pathol. 107:677-684.

10. Felsenstein, S. 1985. Confidence limits on phylogenies: An approach using the bootstrap. Evolution 39:783-791.

11. Finetti-Sialer, M., and Gallitelli, D. 2003. Complete nucleotide sequence of Pelargonium zonate spot virus and its relationship with the family Bromoviridae. J. Gen. Virol. 84:3143-3151.

12. Harrison, B. D., and Murant, A. F. 1977. Nepovirus group. No. 185 in: CMI/AAB Descriptions of Plant Viruses. Commonw. Mycol. Inst./Assoc. Appl. Biol., Kew, England.

13. Hibino, H., Tsuchizaki, T., Usugi, T., and Saito, Y. 1977. Fine structures and developmental process of tubules induced by mulberry ringspot virus and satsuma dwarf virus infections. Ann. Phytopathol. Soc. Japan 43:255-264.

14. Honda, Y., and Matsui, C. 1972. Electron microscopy of intracellular radish mosaic virus. Phytopathology 62:448-452. 
15. Jones, A. T. 2000. Blackcurrant reversion disease-the possible causal agent, eriophyid mite vectors, epidemiology and prospects for control. Virus Research 71:71-84.

16. Kalasjan, J. A., Litvak, L. A., and Marinesku, V. G. 1979. Tubuläre Strukturen in Geweben der Weinrebe nach Infection mit dem Virus der Reisigkrankheit (Grapevine fanleaf virus). Arch. Phytopathol. Pflanzenschutz. Berlin 15:373-376.

17. Kim, K. S., and Fulton, J. P. 1971. Tubules with virus-like particles in leaf cells infected with bean pod mottle virus. Virology 43:329-337.

18. Koenig, R., and Lesemann, D.-E. 1995. Plant viruses in German rivers and lakes I. Tombusviruses, a potexvirus and carnation mottle virus. Phytopathol. Z. 112:105-116.

19. Kusunoki, M., Hanada, K., Iwaki, M., Chang, M. U., Doi, Y., and Yora, K. 1986. Cycas necrotic stunt virus, a new member of nepoviruses found in Cycas revoluta. Host range, purification, serology and some other properties. Ann. Phytopathol. Soc. Japan 52:302-311.

20. Kyriakopoulou, P. E. 1981. Two new virus diseases of tobacco due to Artichoke yellow ringspot virus, alone and in mixed infection with Tobacco mosaic virus. Pages 120-121 in: Proceedings of the Panhellenic Congress of Geotechnical Research, Halkidiki, Greece.

21. Kyriakopoulou, P. E., and Bem, F. P. 1973. Some virus and virus-like diseases of cultivated plants noticed in Greece in the years 1971 and 1972. Pages 21-24 in: Symposium of Agricultural Research. Ministry of Agriculture, Athens, Greece.

22. Kyriakopoulou, P. E., Rana, G. L., and Roca, F. 1985. Geographic distribution, natural host range, pollen and seed transmissibility of Artichoke yellow ringspot virus. Ann. Benaki Phytopathol. Inst. 14:139-145.

23. Le Gall, O., Iwanami, T., Karasev, A. V., Jones, T., Lehto, K., Sanfaçon, H., Wellink, J., Wetzel, T., and Yoshikawa, N. 2004. Genus Cheravirus. Pages 803-805 in: Virus Taxonomy, Classification and Nomenclature of Viruses. Eighth Report of the International Committee on Taxonomy of Viruses. C. M. Fauquet, M. A. Mayo, J. Maniloff, U. Desselberger, and L. A. Ball, eds. Academic Press, New York.

24. Le Gall, O., Iwanami, T., Karasev, A. V., Jones, T., Lehto, K., Sanfaçon, H., Wellink, J., Wetzel, T., and Yoshikawa, N. 2004. Genus Sadwavirus. Pages 799-802 in: Virus Taxonomy, Classification and Nomenclature of Viruses. Eighth Report of the International Committee on Taxonomy of Viruses. C. M. Fauquet, M. A. Mayo, J. Maniloff, U. Desselberger, and L. A. Ball, eds. Academic Press, New York.

25. Le Gall, O., Iwanami, T., Karasev, A. V., Jones, T., Lehto, K., Sanfaçon, H., Wellink, J., Wetzel, T., and Yoshikawa, N. 2004. Family Sequiviridae. Pages 793-798 in: Virus Taxonomy, Classification and Nomenclature of Viruses. Eighth Report of the International Committee on Taxonomy of Viruses. C. M. Fauquet, M. A. Mayo, J. Maniloff, U. Desselberger, and L. A. Ball, eds. Academic Press, New York.

26. Maliogka, V., Dovas, C. I., Efthimiou, K., and Katis, N. I. 2004. Detection and differentiation of Comoviridae species using a semi-nested RT-PCR and a phylogenetic analysis based on the polymerase protein. J. Phytopathol. 152:404-409.

27. Martelli, G. P., Di Franco, A., Russo, M., and Savino, V. 1980. The ultrastructure of Grapevine Bulgarian latent virus infections in natural and artificial hosts. Page 251 in: Proc. 7th Meeting Intern. Counc. for the Study of Viruses and Virus-Like Diseases of the Grapevine, Niagara Falls, Canada. A. J. McGinnis, ed.

28. Milne, R. G. 1984. Electron microscopy for the identification of plant viruses in in vitro preparations. Pages 87-120 in: Methods in Virology. Vol. VII. K. Maramorosch and H. Koprowski, eds. Academic Press, New York

29. Milne, R. G., and Lesemann, D.-E. 1984. Immunosorbent electron microscopy in plant virus studies. Pages 85-101 in: Methods in Virology. Vol. VIII. K. Maramorosch and H. Koprowski, eds. Academic Press, New York.

30. Milne, R. G., Masenga, V., Lenzi, R., and Lovisolo, O. 1980. Radish mosaic virus in Eruca sativa Miller. Phytopathol. Mediterr. 19:145-149.

31. Murant, A. F., Roberts, I. M., and Hutschinson, A. M. 1975. Effects of parsnip yellow fleck virus on plant cells. J. Gen. Virol. 26:277-285.

32. Nurkiyanova, K. M., Ryabov, E. V., Kalinina, N. O., Fan, Y., Andreev, I., Fitzgerald, A. G., Palukaitis, P., and Taliansky, M. 2001. Umbravirus- encoded movement protein induces tubule formation on the surface of protoplasts and binds RNA incompletely and non-cooperatively. J. Gen. Virol. 82:2579-2588.

33. Pringle, C. R. 1998. Virus Taxonomy-San Diego 1998. Arch. Virol. 143:1449-1460.

34. Puffinberger, C. W., and Corbett, M. K. 1985. Euonymus chlorotic ringspot disease caused by Tomato ringspot virus. Phytopathology 75:423428.

35. Rana, G. L., Gallitelli, D., Kyriakopoulou, P. E., Russo, M., and Martelli, G. P. 1980. Host range and properties of Artichoke yellow ringspot virus. Ann. Appl. Biol. 96:177-185.

36. Rana, G. L., Kyriakopoulou, P. E., and Martelli, G. P. 1983. Artichoke yellow ringspot virus. No. 271 in: CMI/AAB Descriptions of Plant Viruses. Commonw. Mycol. Inst./Assoc. Appl. Biol., Kew, England.

37. Rana, G. L., Rosciglione, B., and Cannizzaro, G. 1978. La maculatura anulare gialla del cardo e del carciofo. Phytopathol. Mediterr. 17:63-64.

38. Roberts, I. M. 1988. The structure of Tobacco ringspot Nepovirus: Evidence from electron microscopy. J. Gen. Virol. 69:1831-1840.

39. Rott, M. E., and Jelkman, W. 2001. Characterization and detection of several filamentous viruses of cherry: Adaptation of an alternative cloning method (DOP-PCR) and modification of an RNA extraction protocol. Eur. J. Plant Pathol. 107:411-420.

40. Russo, M., Martelli, G. P., Rana, G. L., and Kyriakopoulou, P. E. 1978. The ultrastructure of Artichoke yellow ringspot virus infections. Microbiologica 1:81-99.

41. Saitou, N., and Nei, M. 1987. The neighbor-joining method. A new method for reconstructing phylogenetic trees. Mol. Biol. Evol. 4:406-425.

42. Saric, A., and Wrischer, M. 1975. Effect of Lettuce-mosaic virus on plant cells. Phytopathol. Z. 90:27-30.

43. Savino, V., Barba, M., Gallitelli, G., and Martelli, G. P. 1979. Two nepoviruses isolated from olive in Italy. Phytopathol. Mediterr. 18:135142

44. Stace-Smith, R., and Hansen, A. J. 1976. Cherry rasp leaf virus. No. 159 in: CMI/AAB Descriptions of Plant Viruses. Commonw. Mycol. Inst./ Assoc. Appl. Biol., Kew, England.

45. Stace-Smith, R., Reichmann, M. E., and Wright, N. S. 1965. Purification and properties of tobacco ringspot virus and two RNA-deficient components. Virology 25:487-494.

46. Terzakis, M., Avgelis, A. D., Jones, A. T., and Katis, N. I. 2002. Artichoke yellow ringspot virus infecting vetch (Vicia sativa) in Greece. Phytoparasitica 30:195-197.

47. Thompson, J. D., Gibson, T. J., Plewniak, F., Jeanmougin, F., and Higgins, D. G. 1997. The ClustalX windows interface: Flexible strategies for multiple sequence alignment aided by quality analysis tools. Nucleic Acids Res. 24:4876-4882.

48. Van der Meer, Q. P. 1997. Old and new crops within edible Allium. Acta Hortic. 433:17-31

49. Van Dijk, P. 1993. Survey and characterization of potyviruses and their strains of Allium species. Neth. J. Plant Pathol. 99:1-48.

50. Van Dijk, P. 1993. Carlavirus isolates from cultivated Allium species represent three viruses. Neth. J. Plant Pathol. 99:233-257.

51. Van Lent, J., Storms, M., Van Der Meer, F., Wellink, J., and Goldbach, R. 1991. Tubular structures involved in movement of cowpea mosaic virus are also formed in infected cowpea protoplasts. J. Gen. Virol. 72:26152623.

52. Voller, A., Bidwell, D. E., and Bartlett, A. 1979. The enzyme-linked immunosorbent assay (ELISA). Dynatech Laboratories, Inc., Alexandria, VA.

53. Walkey, D. G. A. 1990. Virus diseases. Pages 191-212 in: Onions and Allied Crops, Vol. II. H. D. Rabinowitch and J. L. Brewster, eds. CRC Press, Boca Raton, FL.

54. Wieczorek, A., and Sanfacon, H. 1993. Characterization and subcellular localization of tomato ringspot nepovirus putative movement protein. Virology 194:734-742.

55. Winter, S., Purac, A., Leggett, F., Frison, E. A., Rossel, H. W., and Hamilton, R. I. 1992. Partial characterization and molecular cloning of a closterovirus from sweet potato infected with the sweet potato virus disease complex from Nigeria. Phytopathology 82:869-875. 